\title{
Gastrointestinal Disorders in Cat due to Feed Mycotoxin Contamination
}

\author{
Mohammad Sukmanadi ${ }^{1 *}$, Miyayu Soneta Sofyan ${ }^{2}$ \\ ${ }^{1}$ Department of Basic Veterinary Science, Faculty of Veterinary Medicine, Universitas Airlangga, Surabaya, \\ Indonesia, 60115, ${ }^{2}$ Department of Health, Faculty of Vocational Study, Universitas Airlangga, Surabaya, \\ Indonesia, 60115 \\ *Corresponding author: $\underline{\text { moh_sukma@yahoo.com }}$
}

\begin{abstract}
This case reported about mycotoxin contamination on cat feed cause gastrointestinal disorders. A 5 y.o. male domestic short hair cat (Felix domesticus) was brought to the Animal Hospital, Universitas Airlangga with a history has been lethargic and disphagia for 2 days with vomiting a yellow fluid and diarrhea. Bowel movements, increasing in panting, and urination were examined. Observation in cat with gastrointestinal disorders for 5 days in animal hospital. Abnormal intestine and hepatomegaly based on x-ray were confirmed about mycotoxin contamination on cat food. Treatment for contamination on cat food was done by given protexin like probiotic to stimulate a villi intestinal growth and gastric condition. Itraconazole for antifungal to maintanace mycotoxin contamination was also considered. Our prescription was performed for our management treatment with gastrointestinal disoders. In advice, veterinarians should be giving information about the nutritional diet for a pet animal.
\end{abstract}

Keywords: cat food, gastrointestinal disorders, mycotoxin, antifungal

Received: 10 February 2020

Revised: 11 March 2020

Accepted: 11 April 2020

\section{INTRODUCTION}

Cat food is a source of energy needed by cat to live their lives. However, food can be a source of illness if it does not meet the criteria as a good, healthy, and safe food. Various contaminants can contaminate food and feedstuffs so it is not feasible for consumption. The quality of food or food in nature is inseparable from various influences such as environmental conditions, which makes it feasible whether or not a food to be consumed (Bhat and Miller, 2011).

Various pollutants can be contained in food due to the use of contaminated foodstuffs, processing, and storage processes. Among the commonly found contaminants are mycotoxins produced by molds. Mycotoxins are toxic compounds of metabolism of certain fungi that can endanger health pet. The five most important types of mycotoxins are aflatoxin, okratoxin A, zearalenone, trichotesene group and fumonisin. The health effects of pet depend on the type and quantity of mycotoxins consumed. Existence mycotoxins will not only harm animal health, but will also cause residues in the original food product animals such as meat, eggs and milk that can harm human health. Control of mycotoxins through prevention and prevention may help prevent the onset of mycotoxins in feed and animal origin for pet prevent further risks (Ali et al., 2008; Purnama and Samik, 2014).

Any disorder that reduces the digestion or absorption of food, or alters its passage through the digestive tract, can be called a digestive disorder. Gastrointestinal (GI) disorders affect a cat's stomach and intestines, resulting in pain and other problems. Digestive disorders in cats are quite common and most clear up within a few days. But some cats need long-term management because they have regular or permanent digestive problems. GI disorders can lead, to dehydration, acid-base and electrolyte imbalances and malnutrition so it is important to recognize the signs Cats with intestinal disease have a wide range of clinical sign (Boermans and Leung, 2007).

Mycotoxins are toxic compounds of metabolism of certain fungi that can endanger health pet. Existence mycotoxins will not only 
harm animal health, but will also cause residues in the original food product animals such as meat, eggs and milk that can harm human health.

Mycotoxins are secondary metabolites produced by certain species of fungi during their growth in food and feed (Sarma et al., 2017). Mycotoxins have come to prominence since the discovery of aflatoxin which caused Turkey Xdeisease in 1960 (Maryam, 2000). Until now, there are known 300 kinds of mycotoxins (Monson et al., 2015), five of which are very potential to cause diseases both in humans and animals, namely aflatoxin, okratoksin A, zearalenon, trikotesena (deoksinivalenol, toxin T2) and fumonisin (Purnama et al., 2017).

According to Bhat and Miller (2011) about $25 \%-50 \%$ of agricultural commodities polluted the five types of mycotoxins. Diseases caused by exposure to mycotoxins are called mycotoxicosis. Differences in the chemical, biological and toxicological properties of each mycotoxin cause different effects of the toxic effects they cause (Saputro et al., 2020).

In addition, this toxicity is also determined by the dosage or amount of mycotoxin consumed, exposure route, duration of exposure, species, age, sex, physiological status, health and nutrition, and the synergistic effects of various mycotoxinsn simultaneously present in foodstuffs (Bahri et al., 2002). During storage, food or food is easily overgrown by mold. Indonesia's tropical climate with high rainfall, temperature and humidity greatly supports the growth of mold producing mycotoxins. This case was reported a goal to give information about mycotoxin contamination on cat food with gastrointestinal disorders and management therapy.

\section{METHOD}

\section{Signalament}

A 5 y.o. male domestic short hair cat (Felix domesticus) weighing $4.9 \mathrm{Kg}$ was brought to the Animal Hospital Universitas Airlangga with lethargic, disphagia for 2 days with vomiting a yellow fluid and diarrhea, increase in bowel movements and panting and urination were normal.

\section{X-Ray Examination}

A radiography was taken on abdomen. The stomach, kidneys, large intestines, and bladder appeared normal. The liver was slightly enlarged called hepatomegaly. There was a large soft tissue mass effect in the center of the abdomen (Figure 1).

The large radiophague section in the lower center was the problem area. Small intestines observed in the above radiograph. No Obvious masses were found on $\mathrm{x}$-ray but the intestine pattern was not really normal. Normal Intestine show mixed pattern of radiophague (grey) areas and radiolucent (black) areas to indicate intestinal content and gas being mixed around little abnormal digesti (Noviana, 2011).

\section{RESULT AND DISCUSSION}

Based on observation and specialy treatment for contamination on cat food we given protexin like probiotic make a villi small intestinal growth and gastric will be recovery and itraconazole for anti fungal to maintanace mycotoxin contamination. Our prescription is work for our management treatment with gastrointestinal disorders (Table 1). Abnormal intestine based on x-ray and hepatomegaly are confirm about mycotoxin contamination on cat food. Aflatoxins may cause decreased production, immunosuppressive, carcinogenic, teratogenic and mutagenic (Godfrey et al., 2013). Aflatoxins are acutely toxic, carcinogenic, teratogenic, mutagenic, and immunosuppressive to most mammalian species (Hamid et al., 2018). Animal species display differing degrees of susceptibility to aflatoxins, however it is now recognized that young animals are more susceptible (Marchese, 2018; Caloni and Cortinovis, 2011).

After ingestion, aflatoxins are absorbed into the circulatory system, from which they are largely sequestered into the liver, metabolized in the liver by microsomal mixed-function oxidases 


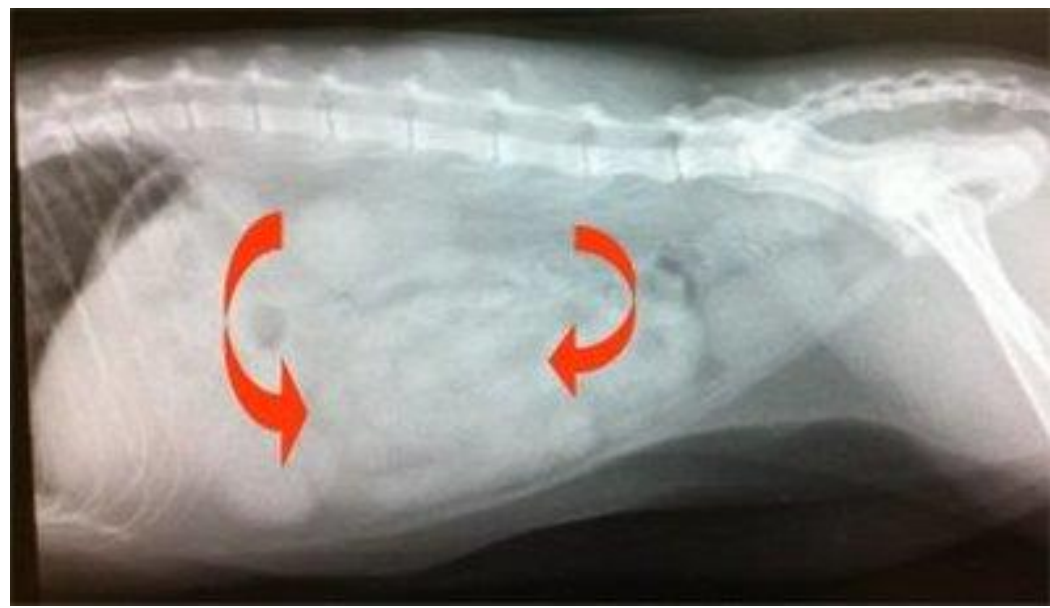

Figure 1. Lateral position of cat with gastrointestinal disorders

Table 1. Prescription during treatment

\begin{tabular}{|c|c|c|c|c|c|c|c|}
\hline Day & Time & $\mathbf{T}$ & $\mathbf{P}$ & $\mathbf{R}$ & Prescription & Feeding & Note \\
\hline \multirow{2}{*}{$1 \mathrm{st}$} & 08.00 & 39.3 & 78 & 90 & $\sqrt{ }$ & & Fluid therapy i.v. \\
\hline & 21.30 & 39.1 & 126 & 42 & & & No urination, diarhea, anorexia \\
\hline \multirow{3}{*}{2 nd } & 08.00 & 39.2 & 110 & 42 & $\sqrt{ }$ & & \\
\hline & 11.00 & 38.7 & 126 & 36 & & & \\
\hline & 14.00 & 38.7 & 120 & 36 & & & \\
\hline \multirow{3}{*}{$3 \mathrm{rd}$} & 06.00 & & & & $\sqrt{ }$ & & Normal urination and defecation \\
\hline & 18.00 & 38.4 & 120 & 30 & $\sqrt{ }$ & Whiskas $^{\circledR}$ & \\
\hline & 21.00 & & & & & Whiskas $^{\circledR}$ & \\
\hline \multirow{4}{*}{ 4th } & 07.00 & 39.1 & 120 & 36 & $\sqrt{ }$ & Whiskas $^{\circledR}$ & Normal urination and defecation \\
\hline & 10.00 & 38.6 & 126 & 48 & & & \\
\hline & 13.00 & 38.0 & 138 & 48 & $\sqrt{ }$ & & \\
\hline & 16.00 & 38.3 & 120 & 36 & & Whiskas ${ }^{\circledR}$ & Normal defecation \\
\hline \multirow{3}{*}{5 th } & 08.00 & & & & & Whiskas $^{\circledR}$ & Normal urination \\
\hline & 10.00 & 38.1 & 126 & 48 & $\sqrt{ }$ & & \\
\hline & 15.00 & 38.1 & 120 & 54 & $\sqrt{ }$ & & \\
\hline
\end{tabular}

Prescription: Protexin, Itraconazole, Dexamethasone $0.5 \mathrm{cc}$;

(T) Temperature; (P) Pulse; (R) Respiration

and cytosolic enzymes (Jayabarathi and Parveen, 2010). The toxicity of aflatoxins is a result of the formation of the reactive aflatoxin B1 8,9epoxide, which binds covalently to cellular macromolecules such as DNA, RNA, and protein enzymes resulting in damage to liver cells (Cullen and Newberne, 2004).

Even aflatoxin B1 that contaminates the feed and consumed dairy cow also does not disappear altogether but turns into aflatoxin M1 that appears in milk that has a toxicity similar to aflatoxin B1. Accumulation of toxins in human or livestock bodies has hepatotoxic effects, liver cancer, mutagenic, teratogenic, and immunosuppressive (Hamid et al., 2019).
Regulation About Mycotoxins has been set forth in WHO 2018. It stated that the maximum limit of aflatoxin B1 (AFB1) aflatoxin and total aflatoxin food products based on peanuts and maize respectively are $20 \mathrm{ppb}$ and total aflatoxin $35 \mathrm{ppb}$. Dairy products have a maximum limit of aflatoxin M1 (AFM1) $0.5 \mathrm{ppb}$. Aflatoxin that contaminates milk comes from the conversion of aflatoxin B1 in feed to aflatoxin M1. The draft of SNI on the limit of contamination of mycotoxins, including 5 types of aflatoxin, deoksinivalenol, fumonisisn, okratoksin $\mathrm{A}$, and patulin are being made. Especially for aflatoxin contamination, the maximum limit assigned to various food products is the same as in the 
WHO (2018)' peanut and its dairy products and corn and its processed products, is $20 \mathrm{ppb}$ for AFB1 and $35 \mathrm{ppb}$ for total aflatoxin, and in milk and its processed products is $0.5 \mathrm{ppb}$ for AFM1 (Wu and Santella, 2015).

In fact, however, existing data indicate that Indonesian agricultural commodities, ie peanuts and maize, are much polluted by aflatoxin, even aflatoxin contamination in both commodities circulating in the market exceeds the maximum limit (> 20ppb) (Purnama et al., 2018). Gastro intestinal problem in cat is a significant health problem, a food preparation consisting of antioxidants, vitamins, trace mineral, and a rational medicine make a cat being health. Additional studies are required to confirm the long-term effect of mycotoxin in these patients as well as in patients with inadequate compliance with lifestyle modification (Houston, 2007).

\section{CONCLUSION}

Gastrointestinal disorders in this case similar to suspect contamination of mycotoxin on cat food. For future advice, nutritional diet preparation becomes important to make sure free from mycotoxin.

\section{ACKNOWLEDGMENT}

The authors acknowledge the animal hospital, Universitas Airlangga for permission during the case report.

\section{REFERENCES}

Ali, N., Sardjono, A., Yamashita, T., Yoshizawa, T. 2008. Natural occurrence of aflatoxins and fusarium mycotoxins (fumonisins, deoxinivalenol, nivalenol, and zearalenon) in corn from Indonesia. Food Add. Contam., 15, 377-384.

Bahri, S., Maryam, R., Widiastuti, R. 2002. Grain and Feed Quality. Bogor.
Bhat, R.V., Miller, J.D. 2011. Mycotoxins and food supply. FAO. Food Nutr. Agric., 1, $27-$ 31 .

Boermans, H.J., Leung, M.C.K. 2007. Mycotoxins and the pet food industry:Toxicological evidence and risk assessment. Int. J. Food Microbiol., 19, 95102.

Caloni, F., Cortinovis. C. 2011. Toxicological effects of aflatoxins in horses. Vet. J., 188, 270-273.

Cullen, J.M., Newberne, P.M. 2004. Acute hepatotoxicity of aflatoxins, In: The toxicology of aflatoxins: human health, veterinary and agricultural significance. Academic Press, San Diego, USA, pp: 36.

Godfrey, S.B., David, K., Lubega, A., OgwalOkeng, J., William, W., David B.K. 2013. Review of the Biological and Health Effects of Aflatoxins on Body Organs and Body Systems, Aflatoxins - Recent Advances and Future Prospects, Mehdi Razzaghi-Abyaneh, IntechOpen.

Hamid, I.S., Aksono, E.B., Sukmanadi, M., Purnama, M.T.E. 2018. Antiangiogenesis activity test of tin leaf (Ficus carica L.) on the number of blood vessels and VEGF expression of chorioallantoic membrane of embryonated chicken eggs. Eur. J. Oncol. Pharm., 1(4), e00007.

Hamid, I.S., Ekowati, J., Purnama, M.T.E. 2019. Kaempferia galanga L. Inhibiting Effect on Vascular Endothelial Growth Factor (VEGF) and Cyclooxygenase-2 (Cox-2) Expression on Endothelium of Chorioallantoic Membrane. Indian Vet. J., 96(09), 80-82.

Houston, J.B. 2007. Clinical Diagnosis and Management by Laboratory Methode. Philadelphia: W.B Saunders Company, pp: 75. 
Jayabarathi, P., Parveen, M.R. 2010. Biochemical and histopathological analysis of aflatoxicosis in Growing hens fed with commercial poultry feed. Int. J. Pharm. Sci. Rev. Res., 3(2), 127-130.

Marchese, S. 2018. Aflatoxin B1 and M1: Biological Properties and Their Involvement in Cancer Development. Toxins, 10, 214.

Maryam, R. 2000. Fumonisin: Kelompok mikotoksin fusarium yang perlu diwaspadai. Jurnal Mikologi Kedokteran Indonesia, 1(1), 51-57.

Monson, M.S., Roger, A., Coulombe, Kent, M.R. 2015. Aflatoxicosis: Lessons from Toxicity and Responses to Aflatoxin B1 in Poultry. Agric., 5, 742-777.

Noviana, D. 2011. Diagnosis Ultrasonografi pada Hewan Kecil. IPB Press. Hal: 17-29.

Purnama, M.T.E., Samik, A. 2014. Potential mycotoxin binders on histopathology of the mammary gland experiencing neoplasia in pregnant mice (Mus musculus) with exposed zearalenone. Vet. Med., 7(1), 73-80.

Purnama, M.T.E., Mustofa, I., Suprayogi, T.W., Samik, A., Prastiya, R.A., Saputro, A.L. 2017. Aluminosilikat berpotensi menekan gangguan reproduksi mikotoksin zearalenon berdasarkan pengamatan jumlah folikel dan ekspresi caspase-9 ovarium. Jurnal Veteriner, 18(2), 175-180.

Purnama, M.T.E., Prastiya, R.A., Saputro, A.L. 2018. Potensi Toksin Binders untuk Mengurangi Efek Mikotoksin Zearalenon terhadap Panjang, Bobot, dan Jumlah Fetus Mencit. Jurnal Veteriner, 19(3), 357-362.

Saputro, A.L., Prastya, R.A., Purnama, M.T.E. 2020. Aluminosilicates Decrease Cytochrome-C and Caspase-3 Expression in Mice Uterine Glands Model Zearalenone Intoxication. Indian Vet. J., 97(02), 30-32.

Sarma, U.P., Bhetaria, P.J., Devi, P., Varma, A. 2017. Aflatoxins: Implications on Health. Indian J. Clin. Biochem., 32(2), 124-133.

World Health Organization (WHO). 2018. Aflatoxis. Geneva https://www.who.int/foodsafety/FSDigest_A flatoxins EN.pdf

Wu, H.C., Santella, R. 2012. The role of aflatoxins in hepatocellular carcinoma. Hepatol. Mon., 12(10HCC), e7238. 